\title{
Preparation of ingredients containing an ACE-inhibitory peptide by tryptic hydrolysis of whey protein concentrates
}

\author{
I.M.P.L.V.O. Ferreira ${ }^{\mathrm{a}, *}$, O. Pinho ${ }^{\mathrm{a}, \mathrm{b}}$, M.V. Mota ${ }^{\mathrm{a}}$, P. Tavares ${ }^{\mathrm{c}}$, A. Pereira ${ }^{\mathrm{c}}$, M.P. Gonçalves ${ }^{\mathrm{d}}$, \\ D. Torres ${ }^{\mathrm{d}}$, C. Rocha ${ }^{\mathrm{e}}, \mathrm{J} . A$. Teixeira $^{\mathrm{e}}$ \\ ${ }^{a}$ REQUIMTE - Serviço de Bromatologia, Faculdade de Farmácia, Universidade do Porto, R. Anibal Cunha 164, 4050-047 Porto, Portugal \\ ${ }^{\mathrm{b}}$ Faculdade de Ciências da Nutrição e Alimentação da Universidade do Porto, Rua Dr. Roberto Frias, 4200-465 Porto, Portugal \\ ${ }^{\mathrm{c}}$ REQUIMTE_Departamento de Química da Faculdade de Ciências e Tecnologia da Universidade Nova de Lisboa, 2825 Monte da Caparica, Portugal \\ ${ }^{\mathrm{d}}$ REQUIMTE_Departamento de Engenharia Química. Faculdade de Engenharia da Universidade do Porto, Rua Dr. Roberto Frias, \\ 4200-465 Porto, Portugal \\ ${ }^{\mathrm{e}}$ Centro de Engenharia de Biológica, IBQF, Universidade do Minho, Campus de Gualtar, 4710-057 Braga, Portugal
}

Received 18 January 2006; accepted 15 June 2006

\begin{abstract}
This study describes the characterisation of whey protein hydrolysates obtained from tryptic hydrolysis to assess their application as ingredients with angiotensin-converting-enzyme (ACE) inhibitory action. The levels of $\alpha$-lactalbumin $(\alpha$-la) and $\beta$-lactoglobulin ( $\beta$-lg) remaining after hydrolysis were quantified. Peptides were separated by RP-HPLC, and Ala-Leu-Pro-Met-His-Ile-Arg (ALPMHIR), the most potent $\beta$-lg-derived ACE-inhibitory peptide was monitored. A correlation curve was established for the production of this peptide as a function of hydrolysis time. Heat-induced gelation of hydrolysates was studied by small-deformation rheology. The gelation times and the strength of the final gels were highly dependent on the degree of hydrolysis. Smaller peptides liberated by hydrolysis contributed to the inability of whey protein hydrolysates to gel.

(C) 2006 Elsevier Ltd. All rights reserved.
\end{abstract}

Keywords: Whey protein concentrates; Trypsin hydrolysis; ACE-inhibitory peptides; Gelation

\section{Introduction}

Whey ingredients are used throughout the world in beverages, bars and other food systems. Newer whey ingredients include hydrolysed whey proteins that contain high levels of bioactive peptides (Foegeding, Davis, Doucet, \& McGuffey, 2002; Gauthier \& Pouliot, 2003; Meisel, 1998). These hydrolysates can be added to special foods to increase value, as enzymatic hydrolysis can optimise their functional properties (e.g., gelling, emulsifying and foaming capacities and solubility) (De Wit, 1998; Melachouris, 1984; Zydney, 1998). Thus, there is considerable commercial interest in the preparation of whey

\footnotetext{
${ }^{*}$ Corresponding author. Tel.: + 35122 2078929; fax: + 351222003977.

E-mail address: isabel.ferreira@ff.up.pt (I.M.P.L.V.O. Ferreira).
}

proteins for food, nutraceutical, and therapeutic applications (Torres, 2005).

Bioactive peptides are often inactive within the sequence of the parent protein and can be released, for example, by enzymatic hydrolysis with digestive enzymes. Bioactive peptide fragments originating from whey proteins should be taken into account as components that have a positive effect on cardiovascular health (Clare \& Swaisgood, 2000; Pihlanto-Leppala, Koskinen, Piilola, Tupasela, \& Korhonen, 2000; Seppo, Jauhiainen, Poussa, \& Korpela, 2003; Yusuf, Lonn, Bosch, \& Gerstein, 1999). For example, certain bioactive peptides may protect against hypertension through angiotensin-converting-enzyme (ACE)-inhibition and opioid-like activity, both in vitro and in animal experiments. The overall effect of an ACE inhibitor is the control of high blood pressure through dilation of blood vessels and its effect on blood volume (Belem, Gibbs, \& 
Lee, 1998; FitzGerald \& Meisel, 2000; Masuda, Nakamura, \& Takano, 1996; Mullally, Meisel, \& FitzGerald, 1997a; Pihlanto-Leppala, Rokka, \& Korhonen, 1998; Sipola et al., 2000; Walsh et al., 2004).

In recent research, ACE-inhibition fragments from both $\alpha$-lactalbumin $(\alpha$-la) and $\beta$-lactoglobulin $(\beta$-lg) were identified. It has been shown that ACE prefers substrates containing a hydrophobic (aromatic or branched sidechains) amino acid residue at the $\mathrm{C}$-terminal position. Whey fractions hydrolysed with trypsin showed ACEinhibition activity (Mullally, Meisel, \& FitzGerald, 1997b).

ACE inhibition is measured by the concentration of substance needed to inhibit $50 \%$ of the original ACE activity $\left(\mathrm{IC}_{50}\right)$. A lower $\mathrm{IC}_{50}$ value indicates higher efficacy. Published research studies on ACE inhibitory activity of various whey-derived peptides show results at a level of 77-1062 $\mu \mathrm{M}$ (Mullally et al., 1997a; Pihlanto-Leppala et al., 2000).

When developed as food ingredients, the processing of these antihypertensive peptides is vital to their activity. For example, heat treatments will have negative effects on the bioavailability of whey peptides, so processors must carefully monitor production parameters. Appropriate selection of enzymes for proteolysis will result in maximum biological activity and will limit the development of bitter flavour notes, with low cost. Trypsin is an interesting enzyme for the liberation of bioactive peptides, and also for the improvement of protein digestibility and for decreasing protein allergenicity, due to its specificity (Mullally et al., 1997b).

Additionally, it is important to study the functional properties of hydrolysates, because hydrolysis produced with different proteolytic enzymes can increase solubility and change gelling properties. Some enzymes can induce gelation following whey protein hydrolysis; others impair gelling properties (Doucet, Gauthier, \& Foegeding, 2001; Foegeding et al., 2002; Otte, Lomholt, Ipsen, \& Qvist, 2000). Gels confer structure, texture and stability to food products; they also allow the retention of large quantities of water and other small molecules inside the food matrix. These aspects are appreciated by processed food manufacturers.

Whey protein concentrates with $\sim 80 \%$ protein are frequently used to fortify various food products, owing to their low fat and lactose contents and high protein levels. This study describes the characterisation of hydrolysates of these whey protein concentrates produced using trypsin with different degrees of hydrolysis. For that purpose, whey protein concentrates were hydrolysed with trypsin to five different degrees of hydrolysis and the remaining levels of $\alpha$-la and $\beta$-lg were quantified. The resulting peptides were separated by reversed phase high-performance liquid chromatography (RP-HPLC), and the most potent $\beta$-lgderived ACE inhibitory peptide, Ala-Leu-Pro-Met-His-IleArg (ALPMHIR) reported to date (Mullally et al., 1997b), was identified and selected to characterize ACE-inhibitory activity of hydrolysates. Additionally, heat-induced gela- tion of three hydrolysates was studied by small-deformation rheology.

\section{Experimental}

\subsection{Substrate and enzymes}

A commercial spray-dried whey protein concentrate (WPC) from bovine milk with $80 \%, \mathrm{w} / \mathrm{w}$, protein (WPC 80), Oragel HG80 from Armor Proteins (Saint Brice en Cogles, France) was used as substrate.

Trypsin from porcine pancreas with an activity of 1800 BAEE units $\mathrm{mg}^{-1}$ of protein ( $1 \mathrm{U}$ hydrolyses $1 \mu \mathrm{mol}$ of $N$ - $\alpha$-benzoy-L-arginine ethyl ester (BAEE) in a reaction volume of $3.2 \mathrm{~mL}$ and $1 \mathrm{~cm}$ light path at $\mathrm{pH} 7.6$ at $25^{\circ} \mathrm{C}$ ) was obtained from Sigma Chemical Co (St. Louis, MO, USA).

\subsection{Hydrolysis of WPC 80}

Solutions of WPC (prepared by suspending $2.5 \mathrm{~g}$ WPC in $50 \mathrm{~mL}$ of distilled water) were warmed to the hydrolysis temperature $\left(37^{\circ} \mathrm{C}\right)$ and adjusted to $\mathrm{pH} 8.0$ with $1 \mathrm{~m}$ $\mathrm{NaOH}$. Enzymatic degradations were performed in a $0.05 \mathrm{~L}$ stirred, tank-type, batch reactor equipped with $\mathrm{pH}$ and temperature control. The $\mathrm{pH}$ was maintained at 8.0 with $0.25 \mathrm{~mol} \mathrm{~L}^{-1} \mathrm{NaOH}$ and the temperature was constant at $37^{\circ} \mathrm{C}$. Trypsin was added at a concentration of $0.2 \mathrm{~g} \mathrm{~L}^{-1}$, and the degree of hydrolysis (DH \%) achieved was measured by the $\mathrm{pH}$-stat method (Adler-Nissen, 1986). Five experiments were performed using the same initial conditions; the hydrolysis reaction was stopped at five different times $(15,30,60,120$ and $180 \mathrm{~min})$ by heating at $80^{\circ} \mathrm{C}$ for $5 \mathrm{~min}$. Five resulting whey protein hydrolysates (WPH) were lyophilised using a CHRIST Alpha 2-4 system (B. Braun Biotech International, Osterode/Harz, Germany).

\subsection{Physicochemical analysis}

The moisture and ash contents were determined according to Food Chemical Codex (FCC, 1981a,b). Total protein content was determined according to the AOAC method (2000). Lactose analyses were carried out in an analytical HPLC unit (Jasco, Tokyo, Japan), equipped with a low-pressure quaternary pump (PU-1580), an evaporative light-scattering detector (LSD-Sedex 75, Alfortville, France) and a type 7125 Rheodyne Injector with a $10 \mu \mathrm{L}$ loop. A Borwin Controller Software (JMBS Developments, Le Fontanil, France) was also used. The column was a Spherisorb $\mathrm{NH}_{2}, 5 \mu \mathrm{m}, 250 \mathrm{~mm}$ length $\times 4.6 \mathrm{~mm}$ internal diameter (Waters Corporation, Massachusetts, Ireland). Elution was carried out with a mixture of $81 \%$ acetonitrile and $19 \%$ of water for $20 \mathrm{~min}$. The flow-rate was $1 \mathrm{~mL} \mathrm{~min}{ }^{-1}$. The temperature of the heated drift tube was $45^{\circ} \mathrm{C}$, the gas pressure was 3.0 bar, and gain 5. Sample preparation involved homogenisation of $200 \mathrm{mg}$ of WPC 80 
or lyophilised hydrolysate with $10 \mathrm{~mL}$ of acetonitrile/water (40:60), followed by filtration with $0.45 \mu \mathrm{m}$ Teknokroma (TR-200106-PVDF, $25 \mathrm{~mm} \quad \varnothing, \mathrm{PK} / 100$ ) syringe filters (Teknokroma, Madrid, Spain).

\subsection{Chromatographic analysis of peptides and proteins}

RP-HPLC was used for the separation of $\beta$-lg, $\alpha$-la and the resulting peptides produced by hydrolysis. An analytical HPLC unit (Jasco) with a Chrompack P-300-RP column was used. Gradient elution was carried out with a mixture of two solvents (solvent A: $0.1 \%$ trifluoroacetic acid (TFA) in water and solvent B: $0.1 \%$ TFA in $80 \%$ aqueous acetonitrile, $[\mathrm{v} / \mathrm{v}])$. Proteins and peptides were eluted as follows: $0-1 \mathrm{~min}, 90 \% \mathrm{~A} ; 1-10 \mathrm{~min}, 90-80 \% \mathrm{~A}$; 10-15 min, $80-75 \%$ A; $15-20 \mathrm{~min}, 75-60 \%$ A; $20-30 \mathrm{~min}$, $60-50 \%$ A; 30-33 min, $50-40 \%$ A; 33-36 min, 40-30\% A; $36-39 \mathrm{~min}, 30-20 \%$ A; $39-41 \mathrm{~min}, 20-0 \%$ A. The flow-rate was $0.5 \mathrm{~mL} \mathrm{~min}^{-1}$. The column was held at ambient temperature and detection was at $215 \mathrm{~nm}$. Total run time was $50 \mathrm{~min}$.

Prior to analysis by RP-HPLC, WPC and WPH were diluted with ultra-purified water, $0.5 \mathrm{~g} \mathrm{~mL}^{-1}$ and $100 \mu \mathrm{L}$ were injected. Standards of bovine $\beta$-lg and $\alpha$-la were supplied by Sigma Chemical Co and dissolved in ultrapurified water that possessed a resistance greater than $15 \mathrm{M} \Omega$. Under the conditions used, the major whey proteins, $\alpha$-la and $\beta$-lg, were well separated and exhibited retention times of 34.5 and $37.5 \mathrm{~min}$, respectively. The chromatographic system was calibrated by the external standard method with solutions that contained bovine $\alpha$-la in the range $0.039-1.0 \mathrm{mg} \mathrm{mL}^{-1}$ and bovine $\beta-1 \mathrm{~g}$ in the range $0.0039-1.0 \mathrm{mg} \mathrm{mL}^{-1}$, the purity of the standards was taken in consideration.

Peptides that eluted around $30 \%$ acetonitrile were collected and lyophilised for further sequencing by automated Edman degradation. Peptide sequence was determined by automated Edman degradation using an Applied Biosystem LC 491 Protein Sequencer (Foster City, USA), after chromatographic separation, collection and freezedrying. The lyophilised ALPMHIR peptide was used as standard for quantification of this peptide in hydrolysates, using an external standard method.

\subsection{Rheological measurements}

The lyophilised WPH was first dispersed in $19 \mathrm{~mm}$ phosphate buffer ( $\mathrm{pH}$ 7.0) to obtain a final concentration of $12 \%$. Protein/hydrolysate concentration for the rheological experiments was limited by the solubility of the less hydrolysed WPH and gelation (even slight) of the most hydrolysed WPH. Hydration of proteins/peptides occurred at room temperature, over $3 \mathrm{~h}$, under gentle stirring. Finally, the ionic strength of the medium was adjusted to $220 \mathrm{~mm}$ (expressed as $\mathrm{NaCl}$ concentration) by addition of $\mathrm{NaCl}$.
Rheological measurements were performed with a controlled-stress rheometer AR2000 (TA Instruments, Delaware, USA) fitted with a rough acrylic plate geometry $(40 \mathrm{~mm}$ diameter, gap $500 \mu \mathrm{m})$. The samples were covered with a thin layer of liquid paraffin to prevent evaporation, after having been placed in the measuring device. Each sample was submitted to a temperature ramp from 20 to $80^{\circ} \mathrm{C}$, at a rate of $2^{\circ} \mathrm{C} \mathrm{min}^{-1}$; then, the temperature was maintained at $80^{\circ} \mathrm{C}$ for $3.5 \mathrm{~h}$. At the end of this time sweep, a frequency sweep ("mechanical spectrum") was recorded over the range $0.06-62.83 \mathrm{rad} \mathrm{s}^{-1}$. The sample was then cooled back to $20^{\circ} \mathrm{C}$, at the same constant rate $\left(2{ }^{\circ} \mathrm{C} \mathrm{min}^{-1} \mathrm{yr}\right.$, and held at $20^{\circ} \mathrm{C}$ for $1 \mathrm{~h}$. Finally, another frequency sweep $\left(0.06-62.83 \mathrm{rad} \mathrm{s}^{-1}\right)$ was recorded at this temperature. During the temperature, time and frequency sweep measurements, a maximum shear strain of $1 \%$ was used. Temperature and time sweeps were performed at $6.28 \mathrm{rad} \mathrm{s}^{-1}$.

\section{Results}

\subsection{Characterization of WPC 80 Trypsin hydrolysates}

The composition of WPC 80 and its WPH at five different degrees of hydrolysis $(0.9,2.2,2.5,2.8$ and $4.2 \%)$ showed no significant differences between moisture, ash, protein, lactose and fat contents of the five WPH $(p<0.01)$ using ANOVA. Mean values were $8.06 \pm 0.4 \%, 4.66 \pm 0.45 \%$, $70.3 \pm 1.2 \%, 7.71 \pm 0.22 \%$ and $9.48 \pm 0.45 \%$, respectively.

The disappearances of $\alpha$-la, $\beta$-lg and the appearance of peptides were evaluated by HPLC (Fig. 1). Hydrolysis of $\alpha$ la was almost complete after $15 \mathrm{~min}$. In contrast, hydrolysis of $\beta$-lg was slower, and about $42 \%$ of the initial level of this protein was intact after $180 \mathrm{~min}$ of incubation. Concentrations of $\beta$-lg quantified by HPLC are presented in Table 1 . In an earlier work performed using different experimental conditions, correlation curves for the hydrolysis of $\beta-\mathrm{lg}$

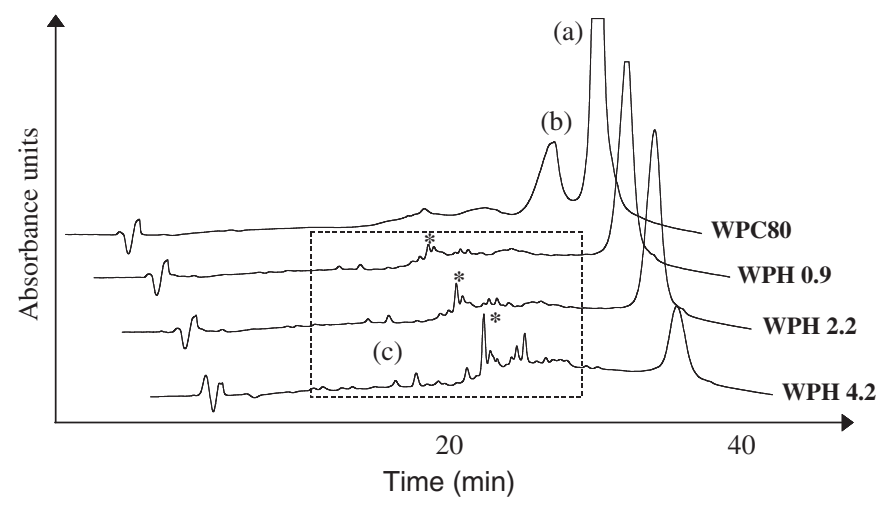

Fig. 1. Typical chromatogram of WPC and three tryptic hydrolysates (WPH0.9, WPH2.2, WPH4.2). (a) $\beta$-lg, (b) $\alpha$-la, (c) the dotted box in the figure points out the elution of tryptic peptides. *Peptide identified as ALPMHIR. Wavelength of absorbance was $215 \mathrm{~nm}$. In the chromatograms for WPH 0.9; WPH 2.0 and WPH 4.2 the zero-time was successively shifted towards the right to show the changes in peaks throughout hydrolysis. 


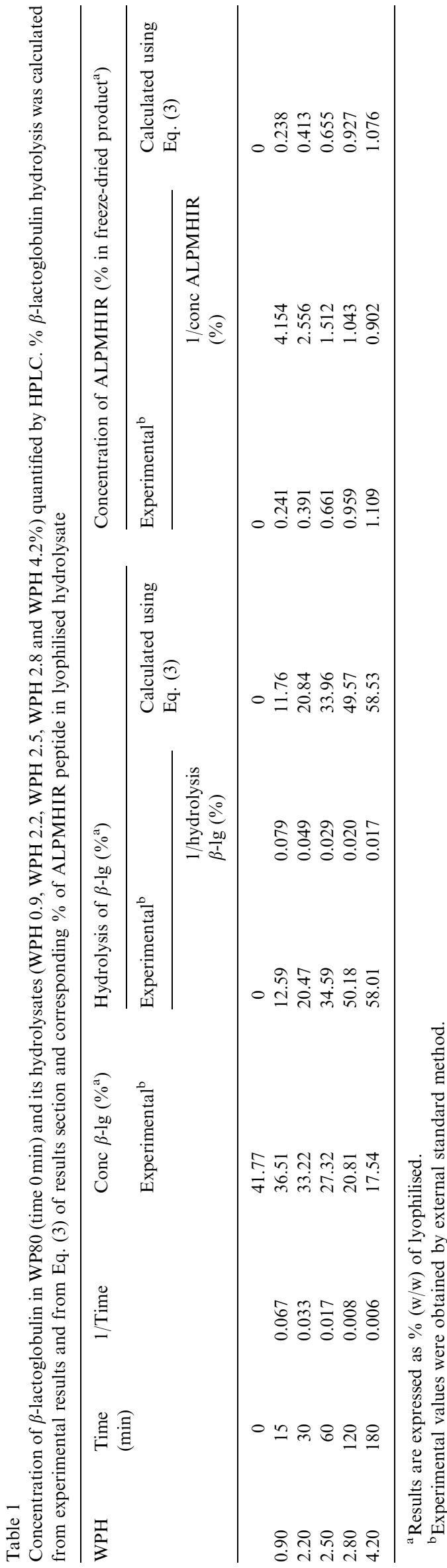

with hydrolysis time were established (Mota et al., 2006). According to that study, the change in level of $\beta$-lg during hydrolysis was hyperbolic; the following equation was used for the model:

$\beta \mathrm{LG}=a \times t /(b+t)$,

where $a$ and $b$ are constants, $\beta \mathrm{LG}$ is $\beta$-lg hydrolysis (\% wt) and $t$ is hydrolysis time (in minutes).

In order to obtain these constants, the inverse of $\beta \mathrm{LG}$ values were plotted against the inverse of time values so that a linear representation could be obtained and constants calculated:

$$
1 / \beta \mathrm{LG}=(b / a \times 1 / t)+1 / a .
$$

The linear functions obtained presented acceptable correlation coefficients. The correlation curve for hydrolysis of $\beta$-lg under the same conditions used in this work was:

$\beta \mathrm{LG}=91.7 t /(102+t)$.

A comparison between experimental and calculated (using Eq. (3)) concentrations of $\beta$-lg in WPC80 and its hydrolysates is presented in Table 1 . The correlation between experimental and calculated data for hydrolysis of $\beta$-lg was 0.9995 .

Hydrolysis with trypsin led to the production of a large number of peptides (Fig. 1). The average retention times for the seven major peaks, in order of increasing elution times, were 18.8, 22.4, 23.6, 25.9, 26.5, 29.4, and $31.7 \mathrm{~min}$, respectively.

Mullally et al. (1997b) described that hydrolysis of $\beta-\lg$ with trypsin released ACE-inhibitory activity peptides eluting at around $30 \%$ acetonitrile, and the most potent peptide was $f(142-148)$, with a charge-to-mass ratio of 837.05. This peptide had an $\mathrm{IC}_{50}$ value of $42.6 \mu \mathrm{mol} \mathrm{L}-1$. Much speculation has been presented as to the contribution of specific amino acid residues/sequences to ACEinhibitory potency. Peptides containing hydrophobic amino acids at the three C-terminal positions are reported to be potent ACE-inhibitors (Cheung, Wang, Ondetti, Sabo, \& Cushma, 1980; Saito, Wanezaki, Kawato, \& Imayasu, 1994). Furthermore, structure-activity data suggest that a positive charge, as on the guanidine group of the C-terminal Arg, contributes substantially to the ACEinhibitory potency of several peptides (Meisel, 1993). The sequence of the $f(142-148)$ peptide, Ala-Leu-Pro-Met-HisIle-Arg (ALPMHIR), reflects these observations. It is interesting to point out that the resistance of this tryptic peptide to further degradation by pepsin and chymotrypsin is controversial (Mullally et al., 1997b; Walsh et al., 2004). Mullally et al. (1997b) demonstrated that this peptide was essentially resistant to further degradation by pepsin and chymotrypsin but Walsh et al. (2004) demonstrated that synthetic ALPMHIR was rapidly degraded upon incubation with human serum.

The peptide $f(142-148)$ does not have the potency of Captopril (a commercial drug inhibitor of ACE, with 


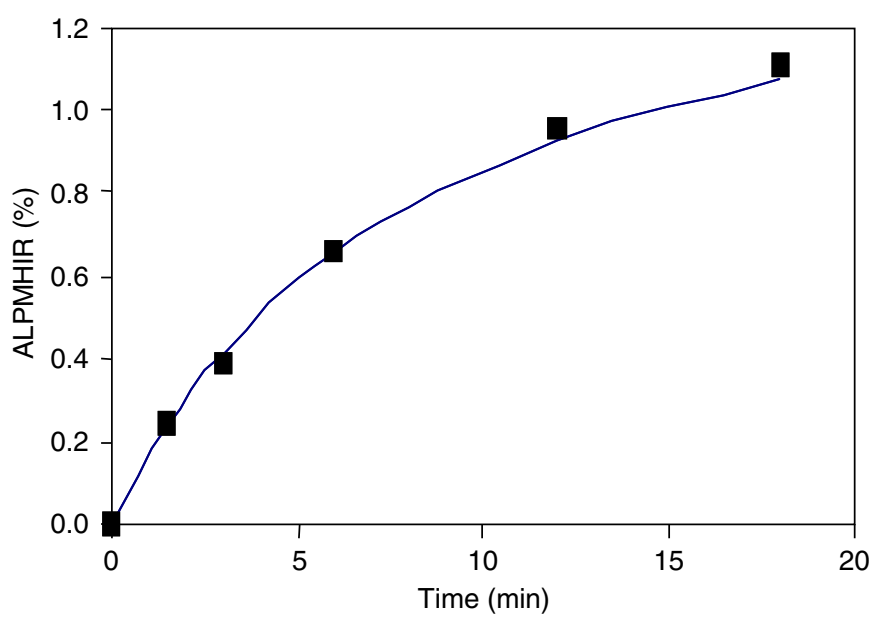

Fig. 2. Plot showing the production of peptide ALPMHIR as a function of time. The linear function that enabled determination of equation curve was: $\%$ ALPMHIR $=(1.585 t / 85.09+t) \ldots$ theoretical data; $\mathbf{a}$ experimental data.

$\left.\mathrm{IC}_{50}=0.006 \mu \mathrm{mol} \mathrm{L}-1\right)$. However, its $\mathrm{IC}_{50}$ value is comparable with those found for other food-derived peptides with potential significant physiological effects as antihypertensive agents (Mullally et al., 1997b).

Edman sequencing revealed that the peptide with a retention time of $23.6 \mathrm{~min}$ from the chromatogram was ALPMHIR. Its concentrations in the five tryptic hydrolysates (WPH) are presented in Table 1. The extent of release of ALMPHIR, i.e., the actual amount detected and the theoretically expected amount from a known quantity of $\beta$ - $\lg$ in the WPC starting substrate, were in good agreement.

A correlation curve was established for the production of the peptide ALPMHIR against hydrolysis time (Fig. 2). The linear function that enabled determination of equation curve were Eq. (4). and (5). The correlation between experimental and calculated data was 0.9968 .

$$
\frac{1}{\% \text { ALPMHIR }}=53.70 \frac{1}{t}+0.631
$$

$$
\% \text { ALPMHIR }=\frac{1.585 t}{85.09+t} .
$$

High hydrolysis times, $>120 \mathrm{~min}$, were required to guarantee that more than $50 \%$ of $\beta$-lg is hydrolysed and a significant amount of this peptide that is a potent inhibitor of ACE in vitro is formed. Concerning the antihypertensive potential of this peptide, it should be pointed out that it is dependent on its ability to be absorbed through the small intestine and to reach target organs without being degraded or inactivated by gastrointestinal or plasma proteinases and peptidases. Few studies in humans have been performed (Walsh et al., 2004).

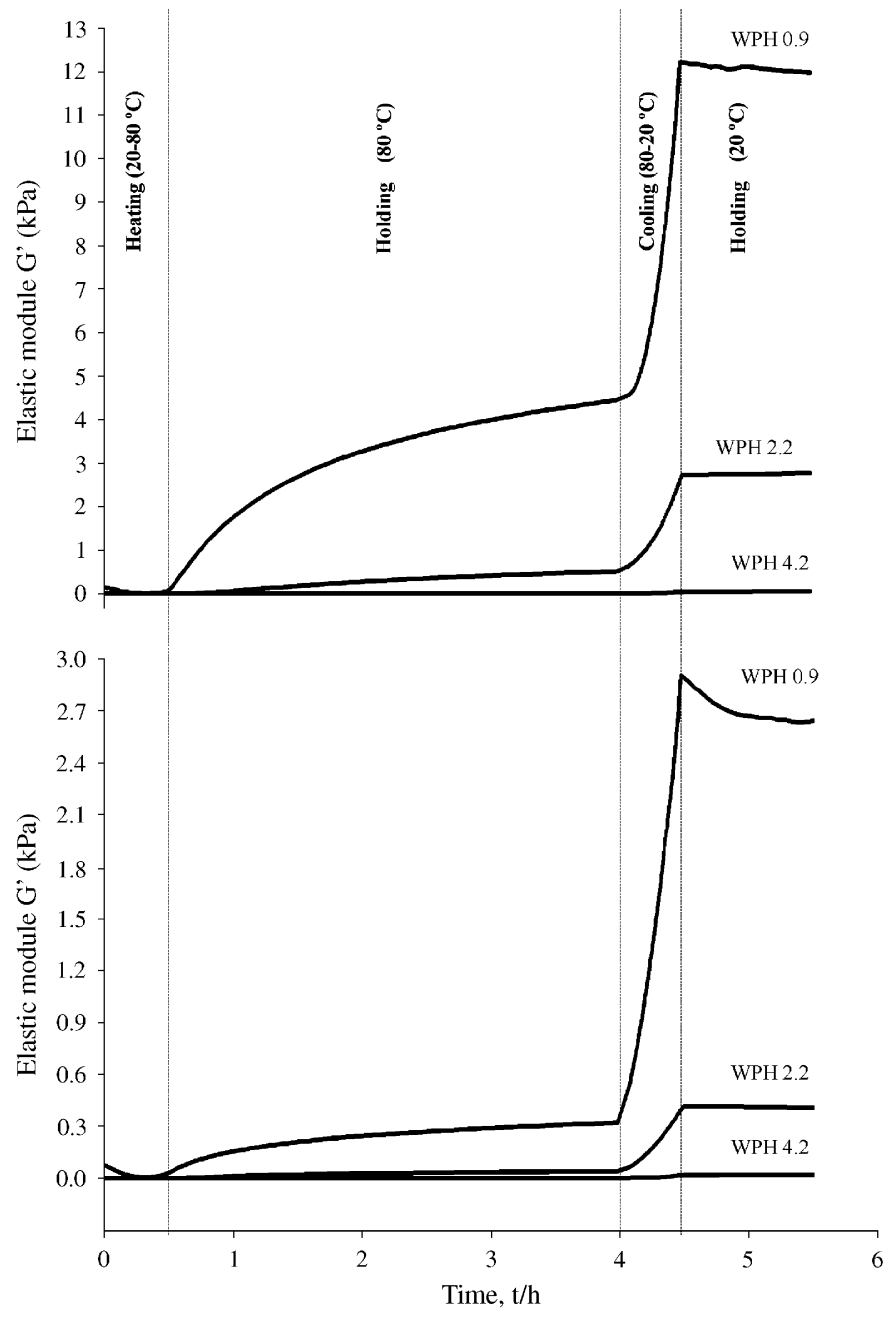

Fig. 3. Changes in the elastic $\left(G^{\prime}\right)$ and viscous $\left(G^{\prime \prime}\right)$ moduli of whey protein hydrolysate dispersions during thermal gelation.

\subsection{Rheology}

Whey proteins in aqueous dispersions, like other globular proteins, can form gels during heating if the protein concentration $(C)$ is greater than the critical concentration for gelation $\left(C_{0}\right)$ and the temperature $(T)$ is greater than the denaturation temperature of the proteins $\left(T_{\mathrm{d}}\right)$ (Clark, 1992). Fig. 3 presents the behaviour of the elastic and the viscous moduli of three WPH dispersions during the thermal process applied. The initial dispersions had the same total protein concentration $(17 \%, w / w)$, the ionic strength was $200 \mathrm{~mm}$, expressed in $\mathrm{NaCl}$ concentration, and the $\mathrm{pH}$ was 7.0; they differed only in the degree of hydrolysis of each hydrolysate involved.

During thermal gelation the elastic modulus $\left(G^{\prime}\right)$ starts to increase and eventually crosses the viscous modulus $\left(G^{\prime \prime}\right)$. Gelation time $\left(t_{\mathrm{g}}\right)$ for protein dispersions is the moment when $G^{\prime}=G^{\prime \prime}$ (Ikeda, Nishinari, \& Foegeding, 2001), at $t_{\mathrm{g}}$, only some protein aggregates are incorporated on the incipient initial three-dimensional network. From that moment, the sol fraction decreases with the incorporation of protein molecules or aggregates in the network (core of 
Table 2

Rheological parameters of whey protein gels

\begin{tabular}{llll}
\hline WPH & $t_{\mathrm{g}}(\mathrm{h})$ & \multicolumn{2}{l}{ Final gel $($ after 5.5 h) } \\
\cline { 3 - 4 } & & $G^{\prime}(\mathrm{kPa})$ & $G^{\prime \prime}(\mathrm{kPa})$ \\
\hline 0.9 & $0.4^{\mathrm{a}}$ & 12.0 & 2.6 \\
2.2 & $0.7^{\mathrm{b}}$ & 2.8 & 0.4 \\
4.2 & $2.9^{\mathrm{b}}$ & 0.05 & 0.02 \\
\hline
\end{tabular}

${ }^{\mathrm{a}} t_{\mathrm{g}}$ occurs during heating step $\left(20-80^{\circ} \mathrm{C}\right)$.

${ }^{\mathrm{b}} t_{\mathrm{g}}$ occurs during kinetics $\left(80^{\circ} \mathrm{C}\right)$.

the gel). The rheological parameters $G^{\prime}$ and $G^{\prime \prime}$ start to increase at different rates, i.e. $>\mathrm{d} G^{\prime} / \mathrm{d} t \gg \mathrm{d} G^{\prime \prime} / \mathrm{d} t$, which reflects the increase in the elasticity of the gel; then, limit values are reached with $G^{\prime} \gg G^{\prime \prime}$ (Clark, 1992; Gosal and Ross-Murphy, 2000).

After that, during the cooling process, $G^{\prime}$ and $G^{\prime}$ increase significantly due to the increase in non-covalent intra- and inter-molecular interactions, resulting in the loss of mobility of the proteins (Renkema, 2001). Spectroscopic studies reveal that hydrogen bonds mainly contribute to the hardening of the whey protein gels (Lefèbvre and Subirade, 2000).

The gelation time (when $G^{\prime}$ equal $G^{\prime \prime}$ ) was highly dependent on the degree of hydrolysis, as well as the strength of the final gels (compare final values of $G^{\prime}$ for each gel), as depicted in Table 2. This behaviour can be explained mainly by the reduced amount of available intact protein for building structure. The stabilisation of the bigger peptides and proteins (components with tertiary structure) by smaller peptides liberated by hydrolysis has also to be considered. Huang, Catignani, and Swaisgood (1999) have reported this effect with the tryptic hydrolysis of a whey protein isolate and have attributed the loss of gelling ability to the stabilisation of $\beta-\lg$ (the main whey protein involved in the gelling phenomena) by a hydrophobic peptide liberated during tryptic hydrolysis.

\section{Conclusions}

ALPMHIR, the most potent $\beta$-lg derived ACE-inhibitory peptide, was assayed and a correlation curve was established for the formation of this peptide during hydrolysis with trypsin. Extensive hydrolysis was required to obtain peptides suitable for functional ingredients, namely ACE-inhibitory effect, more effective gastrointestinal absorption and reduced food allergies. However, smaller peptides liberated by hydrolysis lead to the inability of WPHs to form gel. Thus, the modulation of the gelling properties of whey proteins by enzymatic hydrolysis allows the incorporation of these ingredients, with ACE-inhibitory peptides, in liquid and semi-solid foods with high protein content (e.g., functional drinks with high protein content, dairy desserts, culinary sauces, etc.).

More studies are needed to establish the antihypertensive potential of this peptide in human beings, since this effect is dependent on the ability of this peptide to be absorbed through the small intestine and to reach target organs without being degraded or inactivated by gastrointestinal or plasma proteinases and peptidases.

\section{References}

Adler-Nissen, J. (1986). Enzymic hydrolysis of food proteins. London, UK: Elsevier Applied Science Publishers.

AOAC. (2000). 33.5.03 AOAC Official Method 930.29. Protein in dried milk. AOAC International, Gaitherburg, MD, USA.

Belem, M. A. F., Gibbs, B. F., \& Lee, B. H. (1998). Proposing sequences for peptides derived from whey fermentation. Journal of Dairy Science, 82, 486-493.

Cheung, H. S., Wang, F. L., Ondetti, M. A., Sabo, E. F., \& Cushma, D. W. (1980). Binding of peptide substrates and inhibitors of angiotensinconverting enzyme. Journal of Biological Chemistry, 255, 401-407.

Clare, A., \& Swaisgood, H. E. (2000). Bioactive milk peptides: a prospectus. Journal of Dairy Science, 86, 1187-1195.

Clark, A. H. (1992). Gels and gelling. In H. G. Schwartzberg, \& R. W. Hartel (Eds.), Physical chemistry of foods (pp. 263-305). New York, USA: Marcel Dekker, Inc.

De Wit, J. N. (1998). Nutritional and functional characteristics of whey proteins in food products. Journal of Dairy Science, 81, 597-608.

Doucet, D., Gauthier, S. F., \& Foegeding, E. A. (2001). Rheological characterization of a gel formed during extensive enzymatic hydrolysis. Food Engineering and Physical Properties, 66, 711-715.

FCC. (1981a). Food and nutrition board-national research council. food chemical codex. Washington, USA: National Academy Press p. 518.

FCC. (1981b). Food and nutrition board-national research council. food chemical codex. Washington, USA: National Academy Press p. 466.

FitzGerald, R. J., \& Meisel, H. (2000). Milk protein-derived peptide inhibitors of angiotensin-I-converting enzyme. British Journal of Nutrition, 84(Suppl. 1), S33-S37.

Foegeding, E. A., Davis, J. P., Doucet, D., \& McGuffey, M. K. (2002). Advances in modifying and understanding whey protein functionality. Trends in Food Science and Technology, 13, 151-159.

Gauthier, S. F., \& Pouliot, Y. (2003). Functional and biological properties of peptides obtained by enzymatic hydrolysis of whey proteins. Journal of Dairy Science 86(E. Suppl.), E78-E87.

Gosal, W. S., \& Ross-Murphy, S. B. (2000). Globular protein gelation. Current Opinion in Colloid and Interface Science, 5, 188-194.

Huang, X. L., Catignani, G. L., \& Swaisgood, H. E. (1999). Modification of rheological properties of whey protein isolates by limited proteolysis. Nahrung, 43, 79-85.

Ikeda, S., Nishinari, K., \& Foegeding, E. A. (2001). Mechanical characterization of network formation during heat-induced gelation of whey protein dispersions. Biopolymers, 56, 109-119.

Lefèbvre, T., \& Subirade, M. (2000). Molecular differences in the formation and structure of fine-stranded and particulate $\beta$-lactoglobulin gels. Biopolymers, 54, 578-586.

Masuda, O., Nakamura, Y., \& Takano, T. (1996). Antihypertensive peptides are present in aorta after oral administration of sour milk containing these peptides to spontaneously hypertensive rats. Journal of Nutrition, 126, 3063-3068.

Meisel, H. (1993). In K. D. Schwenke, \& R. Mothes (Eds.), Food proteins. Structure functionality (pp. 67-75). New York, USA: VCH Weinheim.

Meisel, H. (1998). Overview on milk protein-derived peptides. International Dairy Journal, 8, 363-373.

Melachouris, N. (1984). Critical aspects in development of whey protein concentrate. Journal of Dairy Science, 67, 2693-2701.

Mota, M. V. T., Ferreira, I. M. P. L. V. O., Oliveira, M. B. P., Rocha, C., Teixeira, J. A., Torres, D., et al. (2006). Trypsin hydrolysis of whey protein concentrates: Characterization using multivariate data analysis. Food Chemistry, 94, 278-286.

Mullally, M. M., Meisel, H., \& FitzGerald, R. J. (1997a). Angiotensin I converting enzyme inhibitory activities of gastric and pancreatic 
proteinase digests of whey proteins. International Dairy Journal, 7, 299-303.

Mullally, M. M., Meisel, H., \& FitzGerald, R. J. (1997b). Identification of a novel angiotensin-I-converting enzyme inhibitory peptide corresponding to a tryptic fragment of bovine $\beta$-lactoglobulin. FEBS Letters, 402, 99-101.

Otte, J., Lomholt, S. B., Ipsen, R. H., \& Qvist, K. B. (2000). Effect of partial hydrolysis with an immobiled proteinase on thermal gelation properties of $\beta$-lactoglobulin B. Journal of Dairy Research, 67, 597-608.

Pihlanto-Leppala, A., Koskinen, P., Piilola, K., Tupasela, T., \& Korhonen, H. (2000). Angiotensin I-converting enzyme inhibitory properties of whey protein digests: concentration and characterization of active peptides. Journal of Dairy Research, 67, 53-64.

Pihlanto-Leppala, A., Rokka, T., \& Korhonen, H. (1998). Angiotensin I converting enzyme inhibitory peptides derived from bovine milk proteins. International Dairy Journal, 8, 325-331.

Renkema, J. M. S. (2001). Formation, structure and rheological properties of soy protein gels. Ph.D. thesis, Wageningen University, The Netherlands.

Saito, Y., Wanezaki, K., Kawato, A., \& Imayasu, S. (1994). Structure and activity of angiotensin I converting. enzyme inhibitory peptides from sake and sake lees. Biosciences Biotechnology Biochemistry, 58, 1767-1771.
Seppo, L., Jauhiainen, T., Poussa, T., \& Korpela, R. (2003). A fermented milk high in bioactive peptides has a blood pressure-lowering effect in hypertensive subjects. American Journal Clinical Nutrition, 77, 326-330.

Sipola, M., Finckenberg, P., Santisteban, J., Korpela, R., Vapaatalo, H., \& Nurminen, M. L. (2000). Effect of long-term intake of milk products on blood pressure in hypertensive rats. Journal Dairy Research, 69, $103-111$.

Torres, D. (2005). Thermal gelation of enzymatic hydrolysates of whey proteins. Gelling behaviour of mixed aqueous systems peptidespolysaccharides. Academic dissertation, University of Minho, Braga, Portugal.

Walsh, D. J., Bernard, H., Murray, B. A., MacDonald, J., Pentzien, A.K., Wright, G. A., et al. (2004). In vitro generation and stability of the lactokinin $\beta$-lactoglobulin $f(142-148)$. Journal of Dairy Science, 87, 3845-3857.

Yusuf, S., Lonn, E., Bosch, J., \& Gerstein, H. (1999). Summary of randomised trials of angiotensin converting enzyme inhibitors. Clinical and Experimental Hypertension, 21, 835-845.

Zydney, A. L. (1998). Protein separations using membrane filtration: New opportunities for whey fractionation. International Dairy Journal, 8, 243-250. 